\title{
STRUČNI SKUPOVI ZA DJEČJE KNJIŽNIČARE KAO NAČIN STJECANJA KOMPETENCIJA
}

\author{
CHILDREN'S LIBRARIANS \\ CONFERENCES AS A WAY OF ACQUIRING COMPETENCES
}

\author{
Jagoda Ille \\ Knjižnice Grada Zagreba \\ jagoda.ille@kgz.hr \\ Keti Krpan \\ Knjižnice Grada Zagreba \\ keti.krpan@kgz.hr \\ Vjeruška Štivić \\ Narodna knjižnica i čitaonica „Petar Preradović“, Bjelovar \\ vjeruska.stivic@knjiznica-bjelovar.hr
}

UDK / UDC:[021:027.625]:374.7

Pregledni rad / Review paper

Primljeno / Received: 31. 8. 2021.

Prihvaćeno /Accepted: 20. 10. 2021.

\section{Sažetak}

Cilj. Cilj je rada dati pregled održanih skupova za knjižničare za djecu i mladež u organizaciji Knjižnica grada Zagreba - Knjižnice Medveščak i Komisije za knjižnične usluge za djecu i mlade HKD-a u kontekstu stjecanja kompetencija knjižničara.

Pristup/metodologija/dizajn. U radu su korišteni tiskani (dokumentacija o održanim skupovima pohranjena kod Hrvatskog knjižničarskog društva i u Knjižnici Medveščak) i internetski izvori (mrežne stranice Hrvatskog knjižničarskog društva i arhivirane mrežne stranice Knjižnice Medveščak) o povijesti i uvjetima održavanja stručnih skupova u Knjižnici Medveščak te literatura s područja knjižničarskih kompetencija.

Rezultati. Rezultat je rada kronološki pregled stručnih skupova za knjižničare za djecu i mladež održanih u Knjižnici Medveščak od 2006. do 2021. godine s posebnim naglaskom na njihovu ulogu u stjecanju kompetencija za rad u knjižnicama za djecu i

Vjesnik bibliotekara Hrvatske 64, 2(2021), 211-232

ISSN 0507-1925 
mladež kroz obradu različitih ključnih tema. Stručni skupovi omogućili su trajno i pristupačno stjecanje kompetencija na način objavljivanja prezentacija i snimki izlaganja na mrežnim stranicama Hrvatskog knjižničarskog društva sudionicima i knjižničarima koji nisu mogli prisustvovati tijekom održavanja skupova, a u ovom radu su ti izvori sustavno pobrojani.

Praktična primjena. Pomoć organizatorima u planiranju tema budućih stručnih skupova za knjižničare za djecu i mladež te pružanje uvida u mjesta i izvore trajnog i pristupačnog stjecanja kompetencija novim generacijama knjižničara za djecu i mladež.

Društveni značaj. Istaknuta je uloga stručnih skupova kao mjesta neformalnog stjecanja onih kompetencija knjižničara za djecu i mladež koje se ne mogu dobiti kroz formalne ili informalne kanale.

Originalnost/vrijednost. Do ovoga rada nije bilo sustavnog prikaza provođenja stručnih skupova za knjižničare za djecu i mladež koji su se održavali u Knjižnici Medveščak.

Ključne riječi: stručni skupovi, dječji knjižničari, kompetencije

\begin{abstract}
Purpose. The aim of this paper is to give an overview of the conferences for the children's and young adults' librarians organized by the Zagreb City Libraries - Medvescak Public Library and the Croatian Library Association's Commission for Library Services for Children and Young Adults in the context of the librarian competencies acquisition.
\end{abstract}

Approach/methodology/design. The paper research has used the printed (documentation on the previous conferences kept at the Croatian Library Association and at the Medvescak Public Library) and the online sources (web pages of the Croatian Library Association and archived web pages of the Medvescak Public Library). The analysis encompassed the history and the conditions under which the conferences in the Medvescak Public Library were held as well as the relevant literature on the librarian competencies.

Findings. The research has resulted in a chronological overview of the conferences for the children's and young adults' librarians held at the Medvescak Public Library from 2006 to 2021, with special emphasis on their role in acquiring competencies for work in the children's and young adults' libraries. These conferences enabled permanent and simply accessible acquisition of competencies through publishing of the presentations and recordings of the presentations on the website of the Croatian Library Association for the participants and librarians who could not attend live conferences. All these sources are systematically listed in the paper.

Practical implications. The research findings can help the organizers in planning the topics of the future conferences for the children's and young adults' librarians and 
provide insight into the locations and sources of materials for permanent and simply accessible acquisition of competencies for the new generations of the children's and young adults' librarians.

Social implications. The role of professional conferences as places of non-formal acquisition of competencies for the children's and young adults' librarians that cannot be obtained through formal or informal channels was emphasized.

Originality and value. There have not been systematic reviews of the implementation of conferences for the children's and young adults' librarians held at the Medvescak Public Library prior to this paper.

Keywords: conferences, children's librarians, competencies

\section{Uvod}

Ako promotrimo razvoj dječjeg knjižničarstva od sredine prošlog stoljeća do danas, uočavamo velike promjene i pomake. S naglim razvojem tehnologije te su promjene proteklih dvadesetak godina galopirajuće. To potvrđuju činjenice navedene u UNESCO-vom priručniku za rad s djecom u narodnim knjižnicama iz 1957. godine, gdje stoji da se korisnicima knjižnice smatraju samo djeca koja znaju čitati ili pokazuju zanimanje za čitanje. ${ }^{1}$ Danas je situacija znatno drugačija i pravo na dječju knjižnicu ima svako dijete od najranije dobi te mladi koje se prepoznalo kao posebnu korisničku skupinu. ${ }^{2} \mathrm{~S}$ mlađom djecom u dječju knjižnice ulaze i roditelji kao suradnici u ostvarivanju programa za djecu i korisnici dječjih knjižnica s posebnim interesom za roditeljske zbirke. Promjene su vidljive i u građi koja se nudi u dječjim knjižnicama i koja nije više samo tiskana, pa se sukladno tome od dječjeg knjižničara očekuje stjecanje novih vještina jer suvremeni mediji zahtijevaju nove sposobnosti pojedinaca. S vremenom se uvode i novi pojmovi poput medijskog odgoja, digitalne i informacijske pismenosti i dr. U knjižnici se sve više ostvaruju različiti knjižnični programi i provode brojne knjižnične aktivnosti, vrlo često u suradnji s drugim odgojno obrazovnim i kulturnim ustanovama unutar lokalne zajednice. ${ }^{3}$

\footnotetext{
1 Usp. McColvin, L. R. Public library services for children. Paris: UNESCO, 1957. [citirano 2021-05-31]. Dostupno i na: https://unesdoc.unesco.org/ark:/48223/pf0000053875/ PDF/053875engb.pdf.multi.

2 Usp. Koren, M. Pravo djece na informaciju: Vezanost ljudskih prava s knjižničnim uslugama. // Slobodan pristup informacijama u službi kulturnog razvitka: Zbornik radova. / uredile A. Belan-Simić i A. Horvat. Zagreb: Hrvatsko knjižničarsko društvo, 2002. Str. 123-124; 130.

3 Usp. Stričević, I. Dječja knjižnica ukorak s vremenom. // Dječja knjižnica za novo tisućljeće: Zbornik. / uredila R. Javor. Zagreb: Knjižnice grada Zagreba, 2001. Str. 6-7.
} 
Navedene promjene rezultirale su IFLA-inim smjernicama koje prate postojeći razvoj knjižničarstva za djecu, ali i predviđaju njegov daljnji razvoj. Početkom devedesetih godina prošlog stoljeća IFLA je objavila smjernice za dječje knjižnice, ${ }^{4}$ te nakon toga nove smjernice koje su odraz brzih promjena u današnjem informacijskom društvu. ${ }^{5}$ Već 2004. godine Smjernice su objavljene i u hrvatskom izdanju. ${ }^{6}$ Velik utjecaj na zbivanja u dječjem knjižničarstvu u proteklom desetljeću imale su i Smjernice za knjižnične usluge za mladež, objavljene 1996. godine, ${ }^{7}$ a koje su objavljene u hrvatskom izdanju 2004. godine. ${ }^{8}$ One su potaknule osmišljavanje posebnih usluga i programa za mlade na za njih predviđenim odjelima u narodnim knjižnicama, što je omogućilo da se veća pozornost posveti toj izrazito osjetljivoj i zahtjevnoj skupini, ali i da se usluge za djecu usmjeravaju uistinu prema djeci od najranije dobi (čemu su posebno doprinijele Smjernice za knjižnične usluge za bebe i djecu rane dobi) ${ }^{9}$ na dalje.

Nametnulo se veliko pitanje koja sve znanja i vještine trebaju imati knjižničari koji rade s djecom i mladima u knjižnici i kako steći sva potrebna znanja i vještine koja sežu u različita područja informacijskih znanosti, književnosti, pedagogije, razvojne psihologije, komunikologije itd. Naravno da je uz to poželjno da dječji knjižničar ima i odgovarajuće stavove te određene poželjne osobine kako bi na najbolji mogući način pridonio stvaranju zadovoljnih i kvalitetnih ljudi koji onda čine i zadovoljno i kvalitetno društvo u cjelini. Upravo na to upućuju i novija, revidirana izdanja IFLA-inih smjernica za knjižnične usluge za djecu od rođenja do 18 godina iz 2018. godine ${ }^{10}$ te Smjernice za mlade u izdanju HKD-a iz 2009. godine. ${ }^{11}$

${ }^{4}$ Guidelines for children's services. / ed. by Adele M. Fasick. The Hague: IFLA Headquarters, 1991.

5 Guidelines for children's library services. The Hague: IFLA Libraries for Children and Young Adults Section, 2003.

6 Smjernice za knjižnične usluge za djecu: Knjižnične usluge za djecu - važnije no ikada za djecu i njihove obitelji diljem svijeta. / IFLA, Sekcija za djecu i mladež; s engleskoga prevela I. Kranjec. Zagreb: Hrvatsko knjižničarsko društvo, 2004.

7 Guidelines for library services for young adults. / priredili P. Muller and I. Chew. The Hague: IFLA Headquarters, 1996.

8 Smjernice za knjižnične usluge za mladež. / s engleskog prevela I. Kranjec. Zagreb: Hrvatsko knjižničarsko društvo, 2004. (Povremenena izdanja HKD-a; knj. 7)

9 Smjernice za knjižnične usluge za bebe i djecu rane dobi. / glavna urednica M. Willer. Zagreb: Hrvatsko knjižničarsko društvo, 2008.

10 IFLA-ine smjernice za knjižnične usluge za djecu od rođenja do 18 godina. / Sastavila IFLAina Sekcija za knjižnične usluge za djecu i mladež; uredila C. Rankin; prijevod G. Tuškan. 2. izd. (revizija Smjernica iz 2003. godine). Den Haag: IFLA Library Services to Children and Young Adults Section, 2018. [citirano: 2021-10-05]. Dostupno na: https://www.hkdrustvo.hr/hr/strucna_tijela/17/publikacija/599.

11 Smjernice za knjižnične usluge za mladež. Prerađeno izdanje Smjernica koje je 1996. objavio Stalni odbor Sekcije knjižnica za djecu i mladež. / glavna urednica A. Barbarić. Zagreb: Hrvatsko knjižničarsko društvo, 2009. 
Danas se često upotrebljava pojam kompetencija. Što se sve podrazumijeva pod pojmom kompetencija? Prema B. Klaiću ${ }^{12}$ kompetentan je onaj koji je sposoban, upućen, vrstan u nekom području, a kompetencija podrazumijeva mjerodavnost i ovlaštenje. Pretpostavlja se, prema tome, da taj pojam podrazumijeva sveobuhvatnost znanja, vještina, stavova i osobina pojedinca, kao i stupanj u kojem ih je on sposoban upotrijebiti i primijeniti tijekom rada. Proizlazi da se pri tome misli na njegov sveobuhvatni kapacitet i sposobnost za određena postignuća. U tome kontekstu kompetencija ili skup kompetencija znači da pojedina osoba upotrebljava određenu sposobnost ili vještinu za obavljanje zadatka na transparentan način koji omogućuje procjenu njezine razine postignuća. Kompetentnost se razvija tijekom života stalnim edukacijama i u konkretnom, neposrednom radu. U dokumentu pod nazivom Kompetencije informacijskih stručnjaka 21. stoljeća ${ }^{13}$ stoji da informacijski stručnjak kao obrazovana osoba razumije vrijednost nadogradnje i dijeljenja znanja s drugima, a to se najbolje postiže kroz mreže udruga i kroz istraživački rad te predstavljanje njegovih rezultata na konferencijama, u publikacijama, kao i kroz najrazličitije oblike suradnje pridržavajući se etičkih vrijednosti struke.

Stoga su u Hrvatskoj osmišljeni, između ostalog, stručni skupovi za jačanje kompetencija dječjih knjižničara, a jedan od najpoznatijih je onaj koji se od 2006. godine tradicionalno svake godine organizira u Knjižnicama grada Zagreba Knjižnici Medveščak, u suradnji s Komisijom za knjižnične usluge za djecu i mladež Hrvatskog knjižničarskog društva. Upravo se razmišljanjem o osmišljavanju tema stručnih skupova u Knjižnici Medveščak došlo do istraživanja i spoznaja o potrebnim kompetencijama knjižničara u radu s djecom i mladima.

U svom radu I. Martinović i I. Stričević govore kako su kompetencije potrebne za rad dječjeg knjižničara predmet istraživanja u informacijskim znanostima, a s obzirom na specifičnosti odrastajuće korisničke populacije s kojom se radi u knjižnici, one sežu i različita znanstvena područja.$^{14}$ Upravo kroz spoznaje iznesene u tom radu, kao i kroz literaturu na koju se naslanja, došlo se do prepoznavanja kompetencija dječjih knjižničara čije je stjecanje omogućeno sudjelovanjem na stručnim skupovima obrađenima u ovom radu. ${ }^{15}$ Cilj ovoga rada, u kojemu su

12 Klaić, B. Rječnik stranih riječi: Tuđice i posuđenice. Zagreb: Nakladni zavod Matice hrvatske, 1990. Str. 715.

13 Competencies for information professionals of the $21^{\text {st }}$ century. Revised ed. June 2003. [citirano: 2021-05-05]. Dostupno na: https://sla.org/wp-content/uploads/2013/01/0_LRNCompetencies2003_revised.pdf.

14 Usp. Martinović, I.; I. Stričević. Kompetencije dječjih knjižničara: Koliko poznaju literaturu za svoje korisnike. // Vjesnik bibliotekara Hrvatske 56, 3(2013), str. 70. [citirano: 2021-05-10]. Dostupno i na: https://www.hkdrustvo.hr/vjesnik-bibliotekara-hrvatske/index.php/vbh/article/ view/163/158.

15 Competencies for librarians serving children in libraries. Chicago: American Library Association, 2015. [citirano: 2021-10-01]. Dostupno na: https:/www.ala.org/alsc/sites/ala.org.alsc/files/ content/151105_alsc_core-competencies-booklet-nobleeds.pdf. 
korišteni tiskani i internetski izvori o povijesti i uvjetima održavanja stručnih skupova u Knjižnici Medveščak te literatura s područja knjižničarskih kompetencija, jest dati pregled održanih skupova za knjižničare za djecu i mladež u organizaciji Knjižnica grada Zagreba - Knjižnice Medveščak i Komisije za knjižnične usluge za djecu i mlade HKD-a u kontekstu stjecanja kompetencija knjižničara.

\section{Knjižnica Medveščak i Komisija za knjižnične usluge za djecu i mladež Hrvatskog knjižničarskog društva}

Potreba za stalnim stručnim usavršavanjem knjižničara neupitna je, što je navedeno i u IFLA/UNESCO-vom Manifestu za narodne knjižnice iz 1994. godine. ${ }^{16}$ No, unazad 20 i više godina dječji knjižničari nisu imali puno prilika sudjelovati na stručnim skupovima, jednom od oblika stručnog usavršavanja, što zbog tema koje nisu pokrivale njihova specifična područja, što zbog tadašnje prakse da na stručne skupove odlaze diplomirani knjižničari, a u to vrijeme su na dječjim odjelima vrlo često radili knjižničari koji su formalno obrazovani kao odgajatelji ili učitelji razredne nastave s položenim stručnim ispitom za knjižničara. Uočila je to i I. Stričević koja je u to vrijeme bila voditeljica Odjela za djecu Knjižnice Medveščak, pa je sa svojim timom organizirala stručni skup namijenjen dječjim knjižničarima.

Do teme prvog skupa nije se došlo slučajno. Sedamdesetih godina 20. stoljeća dolazi do odmaka od zastarjelih smjernica UNESCO-vog priručnika o knjižničnim službama za djecu u kojemu se nalazi preporuka da se u knjižnice puštaju samo djeca koja znaju čitati ili se zanimaju za čitanje, te se u skladu s društvenim uvjetima među korisnike ravnopravno svrstavaju predškolci kojima se polako prilagođavaju djelatnici, programi, prostor i građa. ${ }^{17}$

Iako se igračka kao dio uređenja Knjižnice Medveščak spominje još 1971. godine $^{18}$, usluga posudbe igračaka formalno je uvedena osnivanjem prve Igraonice i igroteke u Hrvatskoj 1976. godine. O popularnosti i potrebi nove te istovremeno kvalitetno pripremljene i provedene usluge svjedoči rast broja upisanih predškolaca koji od 330 u 1975. godini raste na 675 u 1976. godini, ${ }^{19}$ a Igraonica i igroteka Knjižnice Medveščak 1979. godine postaju ogledne za područje Republike Hrvatske te Knjižnica počinje pomagati pri otvaranju novih igroteka i igraonica u knjižnicama i srodnim ustanovama, pri nabavi, stručnoj i formalnoj obradi te općenito korištenju igračke. Pokretačica i organizatorica uvođenja igračke u knjižnicu, vo-

\footnotetext{
16 IFLA/UNESCO Public library manifesto 1994. [citirano: 2021-05-06]. Dostupno na: https://repository.ifla.org/handle/123456789/186.

17 Usp. McColvin, L. R. Nav. dj., str. 22.

18 Bručić-Dvoršak, S. Kako je nastala igroteka u odjelu za djecu Knjižnice Medveščak u Zagrebu. // Vjesnik bibliotekara Hrvatske 22, 1/4(1976), str. 27.

19 Isto, str. 32
} 
diteljica „Pionirske knjižnice Medveščak“ S. Bručić-Dvoršak za tu je inovaciju primila niz nagrada. Desetljeće kasnije sustavni rad na pružanju usluge posudbe igračaka dovest će Knjižnicu Medveščak na mjesto predstavnika Republike Hrvatske u Međunarodnom udruženju igroteka i igraonica - ITLA.

Knjižnica Medveščak je kao rezultat rada generacija dječjih knjižničara 2006. godine obilježavala 30 . obljetnicu rada Igroteke s igraonicom te je dio slavljeničkih aktivnosti usmjeren prema stručnoj zajednici organiziranjem navedenog stručnog skupa. Skup se održao 3. ožujka 2006. godine pod nazivom „Predškolci u knjižnici: Igraonica i igroteka Knjižnice Medveščak“, a obuhvatio je i programe igraonica drugih knjižnica te se bavio temom organiziranog izvanobiteljskog odgoja, konkretno igraonicama i igrotekama, oblikom koji je zaživio u knjižnicama i održao se do danas kao jedan od stalnih kraćih programa za djecu predškolskog uzrasta mnogih knjižnica u Hrvatskoj. Nakon uvodnog, teorijskog prikaza pod nazivom „Od izvaninstitucionalnih kompenzacijskih programa do izvanobiteljskih programa s kulturološkom, pedagoškom i društvenom dimenzijom i povijesnog pregleda rada Igraonice i igroteke Knjižnice Medveščak “ koji je dala I. Stričević, slijedio je niz izlaganja s primjerima iz prakse slovenskih i hrvatskih narodnih knjižnica te ustanova i udruga koje provode igraonice za predškolsku djecu. Kad taj skup promatramo s aspekta stjecanja kompetencija, one su vezane uz poznavanje specifične korisničke skupine predškolske djece te poznavanje knjižnične građe namijenjene tom uzrastu.

Od prvog skupa za knjižničare za djecu i mladež namjera je bila da skup postane tradicionalan kako bi se popunila praznina stručnih skupova na kojima bi knjižničari koji rade s djecom i mladima mogli usvajati nove spoznaje i stjecati kompetencije s područja dječjeg knjižničarstva. Budući da je I. Stričević u to vrijeme predsjedala Komisijom za knjižnične usluge za djecu i mladež, čiji je bila inicijator za osnivanje pri Hrvatskom knjižničarskom društvu, u organizaciju stručnih skupova uz Knjižnicu Medveščak uključila je i tu Komisiju, s ciljem da se uključi širi krug kompetentnih suradnika u promišljanja o mogućim temama skupova, pri recenziranju prijava i u aktivnosti senzibilizacije dječjih knjižničara u Hrvatskoj za otvaranje važnih tema, pružanju mogućnosti cjeloživotnog obrazovanja, međusobnog upoznavanja, poticanja suradnji i drugoga.

\section{Pregled stručnih skupova u Knjižnici Medveščak}

Od 2006. godine stručni skupovi za knjižničare koji rade s djecom i mladima u narodnim ili školskim knjižnicama održavaju se svake godine u organizaciji Knjižnica grada Zagreba - Knjižnice Medveščak i Komisija za knjižnične usluge za djecu i mladež Hrvatskog knjižničarskog društva. Struktura koja je postavljena na prvom stručnom skupu u Knjižnici Medveščak 2006. godine - uvodna predavanja na aktualnu ili problemsku temu s područja dječjeg knjižničarstva i predavanja 
s primjerima dobre prakse - zadržana je do danas s manjim varijacijama. Nekoliko godina primjeri dobre prakse mogli su se predstaviti usmeno i posterskim izlaganjem, a povremeno su se predstavljali projekti ili akcije Komisije te stručne knjige kolega knjižničara. Skupovi su uglavnom međunarodnog karaktera, jer se pozivaju predavači iz drugih zemalja: Slovenije, Bosne i Hercegovine, Srbije, Njemačke ili skandinavskih zemalja koje imaju visoko razvijene knjižnice i knjižnične usluge i programe.

IFLA-ina Sekcija knjižnica za djecu i mladež (IFLA Libraries for Children and Young Adults Section) 2007. godine priredila je završnu verziju Smjernica za knjižnične usluge za bebe i malu djecu (Guidelines for library services to babies and toddlers), što je bio povod za temu drugog po redu skupa na temu djeca rane dobi u knjižnici. U organizaciji skupa Knjižnici Medveščak priključila se i HKDova Komisija za knjižnične usluge za djecu i mladež na čelu s I. Stričević, koja je ujedno bila dio radne skupine koja je radila na Smjernicama za knjižnične usluge za bebe i malu djecu. Skup je održan 16. ožujka 2007. pod nazivom „Roditelji s bebama i malom djecom - dobro došli u knjižnicu!“‘, programski raspoređen u dva dijela - uvodni dio s pozvanim izlaganjima i dio s primjerima dobre prakse nazvanim „Tržište dobre prakse“. Pozvana izlaganja održali su istaknuti stručnjaci iz akademske zajednice M. Čudina-Obradović, „Važnost 'predškolskog čitanja' i kako ga možemo potaknuti“, D. Maleš „Knjižnica u funkciji jačanja roditeljskih kompetencija“ te L. Tarantello „Dječja knjižnica kao partner u projektu ,Rođeni za čitanje"“, a I. Stričević predstavila je radnu verziju IFLA-inih Smjernica za knjižnične usluge za bebe i djecu do tri godine. Devet primjera dobre prakse održali su knjižničari narodnih knjižnica iz Varaždina, Bjelovara, Zagreba, Koprivnice, Siska, Šibenika, Karlovca i Zadra. ${ }^{20}$ Cilj Skupa bio je osnažiti dječje knjižničare u Hrvatskoj za osmišljavanje i provedbu knjižničnih usluga i programa za najmlađu skupinu korisnika, djecu najranije dobi, od rođenja do 3 godine, koji do unazad 10-ak godina nisu bili dio ciljanih korisničkih skupina knjižnica. Specifičnost te korisničke skupine je što su ona ovisna o svojim roditeljima ili starateljima i odgojiteljima u ostvarivanju prava na čitanje i knjižnične usluge. Stoga, knjižničari trebaju osvještavati odrasle o važnosti čitanja i utjecaja koje ono ima na razvoj dječjeg mozga te im ukazivati na ulogu koju imaju u tom procesu. ${ }^{21}$ Primjeri iz prakse hrvatskih knjižnica prikazani na Skupu bili su vrlo korisni jer su pokazali različite načine uključivanja najmlađih korisnika i odraslih koji se njima bave u knjižnične programe. Tim se Skupom jačaju kompetencije dječjih knjižničara iz

\footnotetext{
20 Cjeloviti program Skupa s poveznicama na prezentacije izlaganja nalazi se na mrežnoj stranici HKD-a: https://hkdrustvo.hr/hr/strucna_tijela/17/publikacija/76.

21 Usp. Stričević, I. IFLA-ine Smjernice za knjižnične usluge za bebe i djecu do tri godine: Radna verzija. (19. 3. 2007.) [prezentacija][citirano: 2021-05-06]. Dostupno na: https://www.hkdrustvo.hr/hr/skupovi/skup/96/sazetak/83.
} 
područja teorije ranog razvoja čitanja te prepoznavanja potreba i potencijala roditelja najmlađih korisnika.

Poticanje čitanja djece osnovnoškolske dobi, jednih od najvjernijih korisnika narodnih knjižnica, bila je tema stručnog skupa koji se održao 14. ožujka 2008. godine u Knjižnici Medveščak pod nazivom „Tko čita, ne skita!: programi za poticanje čitanja djece osnovnoškolske dobi“. Uvodna izlaganja održale su K. Visinko „Kultura čitanja u procesu odrastanja“, T. Jamnik „Knjižničarstvo za mlade u Sloveniji“ i I. Stričević „Kultura čitanja i pismenosti - pogled iz međunarodne perspektive“. Prikazano je i dvanaest primjera dobre prakse te jedno poster izlaganje iz Bjelovara, Zagreba, Splita, Dubrovnika, Samobora, Rijeke, Vinkovaca, Velike Gorice i Delnica. ${ }^{22}$ Promicanje i poticanje čitanja prioritetne su zadaće knjižničara, a na Skupu je naglašena važnost promotivnih aktivnosti knjižnica i njihov mogući utjecaj na knjižnične korisnike. Postavilo se i glavno pitanje za sve one koji se bave promocijom čitanja: koje su kompetencije potrebne knjižničaru za rad na promicanju čitanja iz užitka s onima koji nisu korisnici knjižnica i s onima koji ne čitaju. K. Visinko je istaknula potrebu provedbe istraživanja kulture čitanja djece i mladeži, korisnika dječjih i gradskih knjižnica, s ciljem dobivanja podataka vezanih uz njihove čitalačke sposobnosti i vještine te čitateljske potrebe i interese radi usmjeravanja razvijanja kulture čitanja u školskom i izvanškolskom sustavu. ${ }^{23}$ Primjeri dobre prakse potvrdili su značaj i širinu teme poticanja čitanja djece osnovnoškolske dobi raznolikim uslugama i programima koji su predstavljeni stručnoj zajednici. S aspekta stjecanja kompetencija skup je ponudio znanja i vještine vezane uz razvoj čitanja i promicanje čitanja.

Stručni skup koji se održao 20. ožujka 2009. godine bavio se temom knjižničnih programa i usluga za mladež, a nosio je naslov „Tinejdžer u knjižnici. Upomoć!“. Mladež i tinejdžeri kao jedna od podskupina mladeži, zasigurno su najzahtjevnija skupina korisnika zbog svojih specifičnih obilježja. Skup je imao za cilj definirati mladež i tinejdžere i odrediti ih kao korisničku skupinu te omogućiti razmjenu primjera dobre prakse, odnosno stručnoj zajednici predstaviti programe koji se provode u hrvatskim knjižnicama. Održana su tri pozvana izlaganja: D. Miljković „Životni ciljevi adolescenata“, I. Stričević i V. Tibljaš, „Knjižnične usluge za mlade: zašto i zašto ne?“ te A. Stropnik „Odjel za mladež u narodnoj knjižnici: strategije osnivanja“. U sklopu „Tržišta dobre prakse“ održano je sedam izlaganja knjižničara iz hrvatskih knjižnica iz Zagreba, Bjelovara, Pazina, Splita, Karlovca i Rijeke. ${ }^{24} \mathrm{Na}$ tom skupu uvedena je sesija Rasprava i zaključci skupa,

22 Cjeloviti program Skupa s poveznicama na prezentacije izlaganja nalazi se na mrežnoj stranici HKD-a: https://hkdrustvo.hr/hr/strucna_tijela/17/publikacija/93.

23 Usp. Visinko, K. Kultura čitanja u procesu odrastanja. (14. 3. 2008.) [prezentacija][citirano: 2021-05-06]. Dostupno na: https://www.hkdrustvo.hr/hr/skupovi/skup/122/sazetak/27.

24 Cjeloviti program Skupa s poveznicama na prezentacije izlaganja nalazi se na mrežnoj stranici HKD-a: https://hkdrustvo.hr/hr/strucna_tijela/17/publikacija/128. 
gdje je predviđeno da se još jednom sagledaju sva izlaganja te sudionici svojim promišljanjima doprinesu zaključcima skupa. Na kraju je najavljeno objavljivanje hrvatskog izdanja IFLA-inih Smjernica za knjižnične usluge za mladež, publikacije koja uz dodatke o Webu 2.0 u knjižnici, sadrži i primjere prakse iz hrvatskih knjižnica. Sintagma koja je više puta isticana tijekom Skupa - S njima, a ne za njih (poznata sintagma V. Walter i E. Meyers) ${ }^{25}$ - ujedno je bila i glavni zaključak Skupa. Glavno obilježje knjižničarstva za mladež je u pristupu koje se ogleda u usmjerenju na mladež kao aktivne sudionike i stvaranju partnerskog odnosa s njima, tako da mladi korisnici nisu samo pasivni primatelji usluga, već proaktivni korisnici knjižnica. Skup je pružio mogućnost jačanja kompetencija dječjih knjižničara na polju poznavanja specifične korisničke skupine te oblikovanja i pružanja njima prilagođenih usluga.

Dječji knjižničari u ostvarivanju svojih zadaća i ciljeva usko surađuju s ustanovama s područja odgoja i obrazovanja, dječjim vrtićima, osnovnim i srednjim školama. Suradnja sa školama ponajprije se ostvaruje preko školskih knjižnica, odnosno, školskih knjižničara. Zato je kao tema skupa koji se održao 19. ožujka 2010. godine odabrana suradnja dječjih i školskih knjižnica, a Skup je nosio naziv „Zajedno na dobrobit naših korisnika: suradnja dječjih i školskih knjižnica“. U organizaciji toga skupa Knjižnici Medveščak i Komisiji za knjižnične usluge za djecu i mladež pridružila se i HKD-ova Komisija za osnovnoškolske knjižnice. Održana su dva pozvana izlaganja „Dječje i školske knjižnice - od suradnje do partnerstva“ I. Stričević i „Školske knjižnice - prirodni partneri dječjih knjižnica“ školske knjižničarke M. Milinović. Knjižničari iz narodnih i osnovnoškolskih knjižnica iz Karlovca, Koprivnice, Osijeka, Rijeke, Splita, Vukovara, Zagreba i Zaprešića održali su izlaganja u dijelu rezerviranom za primjere dobre prakse. ${ }^{26}$ Program Skupa pratili su podjednako dječji i školski knjižničari, a to se nastavilo i na budućim skupovima koji su ipak primarno namijenjeni knjižničarima narodnih knjižnica. Ono što povezuje narodne i školske knjižnice jest korisnik, pa je u svom uvodnom izlaganju tada aktualna predsjednica Komisije za školske knjižnice, M. Milinović istaknula: „Ako nam je najvažniji korisnik (učenik), suradnja je nužnost. “27 Suradnja i partnerstvo preporučeno je i u IFLA-inim i UNESCO-ovim smjernicama, što je istaknuto u gotovo svim izlaganjima. Na Skupu su predočeni rezultati znanstvenih istraživanja u području suradnje dviju vrsta knjižnica te primjeri dobre prakse koji daju ideje o raznovrsnosti načina suradnje, a zaključeno je da je bit njihove suradnje poboljšati knjižnične usluge za djecu i mladež u zajed-

${ }_{25}$ Usp. Walter V. A.; E. Meyers. Teens and libraries: Getting it right. Chicago: American Library Association, 2003.

26 Cjeloviti program Skupa s poveznicama na prezentacije izlaganja nalazi se na mrežnoj stranici HKD-a: https://hkdrustvo.hr/hr/strucna_tijela/17/publikacija/155.

27 Milinović, M. Školske knjižnice - prirodni partneri dječjih knjižnica. 2010. [prezentacija] [citirano 2021-06-07]. Dostupno na: https://www.hkdrustvo.hr/hr/skupovi/skup/165/sazetak/52. 
nici u kojoj djeluju s ciljem zajedničkog usmjerenog djelovanja prema promociji knjige i čitanja među djecom, osposobljavanju djece za samostalno istraživanje te koordinirano razvijanje poticajnih kulturnih okružja u kojima djeca odrastaju. $\mathrm{Na}$ kraju skupa predstavljeno je hrvatsko izdanje novih IFLA-inih Smjernica za knjižnične usluge za mladež. ${ }^{28}$ Prepoznat je potencijal Skupa za jačanje kompetencija iz kategorije vještina suradnje i umrežavanja.

Fenomenom interneta i djece u kontekstu knjižnica bavilo se na stručnom skupu pod nazivom "Djeca na internetu u knjižnici" koji se održao 18. ožujka 2011. godine. Internet je postao sveprisutan medij koji nije zaobišao niti knjižnice. Posebno su mu sklona djeca i mladi koji pomoću interneta brže i lakše dolaze do informacija te na njemu provode slobodno vrijeme radi igre, razbibrige i druženja. Iako je među knjižničarima bilo stavova da računalima i internetu nije mjesto u dječjoj knjižnici jer je poznat loš utjecaj ekrana na zdravlje djece, knjižničari naprosto nisu mogli zanemariti činjenicu da djeca i mladi puno vremena borave na računalu koristeći internet. Morali su iznaći načine na koji će njihovi korisnici sigurno i pametno koristiti internet, što je svakako uključivalo rad na informatičkom, medijskom i informacijskom opismenjavanju djece i mladih. Da su u tome bili uspješni pokazalo je i šest primjera dobre prakse iz Zagreba, Karlovca, Rijeke, Pazina, Splita i Zadra koji su bili prikazani na Skupu. Primjerima su prethodila uvodna izlaganja koja su bila usmjerena na znanstvena istraživanja o utjecaju interneta na psihički razvoj djece i mladih, na dokumente Europske unije i IFLA-e o korištenju interneta u knjižnici i važnosti informacijskog opismenjavanja koje provode knjižničari u narodnim i školskim knjižnicama: M. Krmek „Djeca i internet - prednosti i nedostaci“, V. Tibljaš i D. Brunac „Internet i knjižnične usluge za djecu: preporuke IFLA-e i Europske unije“, I. Stričević „Informacijska pismenost i uloga dječjih knjižničara“". ${ }^{29}$ Nakon rasprave glavna urednica za Povremena izdanja HKD-a A. Barbarić predstavila je hrvatsko izdanje novih IFLA-inih Smjernica za informacijsku pismenost $u$ cjeloživotnom učenju. ${ }^{30}$ Skupom se jačaju kompetencije dječjih knjižničara vezane uz informacijsku pismenost te poznavanje i korištenje novih tehnologija.

Stručni skup održan 23. ožujka 2012. godine tematski se bavio oblicima suradnje dječjih knjižničara i roditelja u narodnim knjižnicama, a nosio je naziv „Suradnja dječjih knjižničara i roditelja“. O suradnji roditelja i dječjih knjižničara problematiziralo se već na ranijim skupovima Knjižnice Medveščak i Komisije za knjižnične usluge za djecu i mladež, no važnost te teme za knjižničare nalagala je da ju se posebno razmotri. Održana su tri pozvana izlaganja „Nove paradigme

\footnotetext{
28 Smjernice za knjižnične usluge za mladež. / glavna urednica A. Barbarić. Nav. dj.

29 Cjeloviti program Skupa s poveznicama na prezentacije izlaganja nalazi se na mrežnoj stranici HKD-a: https://hkdrustvo.hr/hr/strucna tijela/17/publikacija/175.

30 Smjernice za informacijsku pismenost u cjeloživotnom učenju: Završna verzija. / uredio J. Lau. Zagreb: Hrvatsko knjižničarsko društvo, 2011.
} 
obiteljskog odgoja“ D. Maleš, „Osobine današnjih roditelja“ R. Miljević-Riđički i „Uloga knjižnice u obrazovanju roditelja“ I. Stričević te osam izlaganja primjera dobre prakse iz narodnih knjižnica u Hrvatskoj. ${ }^{31}$ Roditelji su dječjim knjižničarima prirodni i logični suradnici, osobito u ranoj dobi djece, te su izdvojeni kao skupina korisnika dječjih knjižnica kojima se posvećuje posebna pozornost. Suradnja na području razvoja rane i obiteljske pismenosti može se odvijati na više razina, od informiranja i edukacije roditelja do njihova aktivnog uključivanja u provedbu aktivnosti u igraonici i knjižnici, što su izvrsno pokazali primjeri dobre prakse prikazani na skupu. Na kraju programa predstavljen je Festival dječje knjige „Monte Librićc“. I taj je skup ponudio sudionicima mogućnost usvajanja kompetencija vezanih uz suradnju s vanjskim dionicima, kao i prepoznavanje potreba i potencijala roditelja.

Dostupnost i otvorenost dječjih knjižnica istaknuta je u svim važnijim dokumentima za knjižnične usluge za djecu i mlade kojima je temelj UN-ova Konvencija o pravima djeteta koja naglašava pravo svakog djeteta da u potpunosti razvije svoje potencijale, pravo na slobodan i besplatan pristup informacijama, građi i programima, podjednake uvjete za sve, bez obzira na dob, rasu, spol, vjersku, nacionalnu ili kulturnu pripadnost, jezik, socijalni status, te umne i tjelesne sposobnosti i vještine. ${ }^{32}$ Tom temom bavilo se na stručnom skupu „Dječja knjižnica dostupna svima“ održanom 22. ožujka 2013. godine, koji je naglasio da knjižnični programi i usluge trebaju biti podjednako dostupni svoj djeci, pa i onoj koja imaju posebne potrebe, uključujući djecu i mlade s teškoćama u razvoju, one koji žive u specifičnim okolnostima i one koji su na bilo koji način deprivirani, kao što su djeca i mladi u ruralnim područjima ili iz geografski udaljenih područja, oni koji su na dugotrajnom liječenju u bolnicama i pripadnici nacionalnih manjina, kao i djeca i mladi iz obitelji koje žive u teškim socijalnim i ekonomskim prilikama. Namjera organizatora bila je da se u uvodnim izlaganjima prikažu teorijski okviri za pružanje kvalitetnih knjižničnih usluga i provedbu programa za djecu i mlade, a da se u primjerima dobre prakse knjižnice osvrnu na probleme i prepreke na koje su nailazile u osmišljavanju, planiranju i provođenju takvih usluga te kako su ih riješile. Pozvana izlaganja održale su tada aktualna pravobraniteljica za djecu Republike Hrvatske M. Jelavić „Jednaka prava za svu djecu: knjižnica kao informacijsko središte“, P. Vilar, „Dostupnost slovenskih knjižnica djeci i mladima: primjeri bolničkih pacijenata, zatvorenika i djece s poteškoćama u razvoju“ te $\mathrm{D}$. M. Gabriel i D. Semenić-Premec „Pregled razvoja knjižničnih usluga i programa u Hrvatskoj na dobrobit djece i mladih koji ne mogu koristiti standardne knjižnične

\footnotetext{
31 Cjeloviti program Skupa s poveznicama na prezentacije izlaganja nalazi se na mrežnoj stranici HKD-a: https://hkdrustvo.hr/hr/strucna_tijela/17/publikacija/205.

32 Konvencija o pravima djeteta. [citirano: 2021-06-08]. Dostupno na:

https://www.unicef.hr/wp-content/uploads/2017/05/Konvencija_20o_20pravima_20djeteta_full. pdf.
} 
usluge“. Zbog velikog broja prijava za dio stručnog skupa posvećenog primjerima dobre prakse prvi je puta je organizirana sesija izlaganja na posterima na kojoj su bili predstavljeni neki od primjera dobre prakse. Ukupno je održano dvanaest primjera dobre prakse. ${ }^{33} \mathrm{Na}$ kraju skupa predstavljeni su rezultati istraživanja koje je 2012. godine za UNICEF provela N. Pećnik pod nazivom „Usluge za podršku roditeljstvu i ranom razvoju u zajednici“" o tome koliko često roditelji čitaju djeci, te je najavljena nacionalna kampanja „Čitaj mi!“ za promicanje čitanja naglas djeci od rođenja koju su pokrenuli HKD-ova Komisija za knjižnične usluge za djecu i mladež s partnerima. Na skupu je između ostalog istaknuto da je potrebno razvijati društvenu odgovornost u prepoznavanju potencijala knjižnica kao pozitivnog, poticajnog i sigurnog okruženja značajnog za razvoj pismenosti, cjeloživotno učenje, kvalitetno provođenje slobodnog vremena djece i mladih. Knjižnice su spremne dati doprinos i kod izgradnje cjelovitog sustava zaštite i promicanja prava djece s posebnim potrebama. No knjižnice treba osnažiti u radu na tim područjima utvrđivanjem zakonskih akata koji se odnose na određivanje minimalnih uvjeta za rad dječje knjižnice (primjerice, prostor, kadrovi, oprema i dr.), povećati društvenu, javnu i financijsku potporu knjižnicama, intenzivirati suradnju knjižnica s kulturnim, odgojno-obrazovnim, zdravstvenim i socijalnim ustanovama, udrugama i lokalnom zajednicom. Skup je omogućio jačanje kompetencija tako što su sudionici upoznati s kategorijama korisnika s posebnim potrebama i korisnika različitih kultura, s naglaskom na razvoj vještina prosocijalnog ponašanja.

Preseljenje Odjela za djecu i Odjela za mladež Knjižnice Medveščak na novu lokaciju, u obnovljeni i preuređeni prostor bivše knjižare u Zvonimirovoj 17 u Zagrebu, bio je povod da se na stručnom skupu namijenjenom dječjim knjižničarima problematizira tema zgrada, prostora i opreme u kojima se nalaze i koje koriste knjižnice za djecu i mlade. Skup pod nazivom „Zgrade, prostori i oprema dječjih knjižnica i knjižnica za mlade“ održao se 28. ožujka 2014. godine upravo u novouređenom prostoru koji je poslužio kao pozitivan primjer promišljeno uređenog knjižničnog prostora prvenstveno namijenjenog djeci rane do tinejdžerske dobi. Održana su tri pozvana izlaganja „Energetska učinkovitost, toplinska, svjetlosna i akustična ugodnost knjižničnih prostora za djecu i mladež“ Lj. Miščevića, „Dječje knjižnice u Hrvatskoj - prostori kakve želim“, F. Bišćan, te „The transformation of a library into a magic place: children's participation in the architecture of the library" M. Corbiere. Od primjera dobre prakse prikazano je osam izlaganja dobre prakse narodnih knjižnica iz Zagreba, Novske, Rijeke, Splita i Pazina te pet posterskih izlaganja u kojima su svoj rad predstavile knjižnice iz Labina, Bjelovara, Karlovca, Osijeka i Šibenika. ${ }^{34}$ Fokus pozvanih izlaganja bio je na energetskoj

\footnotetext{
33 Cjeloviti program Skupa nalazi se na mrežnoj stranici HKD-a: https://hkdrustvo.hr/hr/strucna_tijela/17/publikacija/235.

34 Cjeloviti program Skupa nalazi se na mrežnoj stranici HKD-a: https://hkdrustvo.hr/hr/strucna_tijela/17/publikacija/262.
} 
održivosti, prilagođenosti prostora i opreme potrebama i željama djece i mladih te funkcioniranja knjižnica kao trećeg prostora u lokalnoj zajednici. Prikazani su hrvatski primjeri novosagrađenih, obnovljenih, prenamijenjenih i idejnih projekata knjižničnih zgrada i prostora za djecu i mlade. Primjeri dobre prakse i ovoga puta bili su podijeljeni u dvije sesije, izlaganja i posteri, a pokazali su da su prostorni uvjeti knjižnica u Hrvatskoj različiti: od namjenski sagrađenih i novosagrađenih prostora, do preuređenih i prenamijenjenih. Ovisno o raznim čimbenicima, prostori knjižnica za djecu i mlade nastoje se urediti prema prihvaćenim pravilima struke te prilagoditi korisnicima. Zaključno, dječje knjižnice trebaju biti ugodni, sigurni, funkcionalni, vizualno privlačni i odgovarajuće opremljeni prostori koji odgovaraju potrebama i zahtjevima djece i mladih. Kako bi se to postiglo, nužno je razumijevanje osnivača te suradnja arhitekata i dizajnera interijera sa strukom. Skupom se potiče razvoj kompetencije dječjih knjižničara u prepoznavanju važnosti i primjerenosti fizičkog prostora knjižnice.

Stručni skup „Dječje knjižnice - iskorak u virtualno“ održan je 27. ožujka 2015. godine na temu knjižničnih usluga i programa za djecu i mlade u virtualnom prostoru. Knjižnice prilagođavaju postojeće usluge i stvaraju nove koje će biti u skladu s novim generacijama djece i mladih koja odrastaju uz računala i internet, tzv. Generacija Z. Uvodna izlaganja održali su P. Pale „Djetinjstvo s internetom u džepu“, D. Mučnjak „Knjižničari - tehnofobi ili tehnofili?“, S. Božin „Generacija 2.0: knjižnice za djecu i mlade u Njemačkoj“ i V. Tibljaš „Web (o) djeci, web (s) mladima“". Okosnica uvodnih izlaganja bilo je određivanje okruženja u kojem odrastaju današnja djeca te ukazivanje na izazove koji se u tom kontekstu postavljaju pred knjižnice. Prikazani primjeri dobre prakse iz knjižnica iz Koprivnice, Zaprešića, Kaštela, Zagreba, Zlatar Bistrice, Rijeke, Zadra i Bjelovara pokazali su da se hrvatske knjižnice prilagođavaju novim generacijama mladih korisnika kreiranjem i provođenjem novih virtualnih usluga i programa. ${ }^{35}$ Načini na koje djeca uče, čitaju i provode slobodno vrijeme uvjetovani su brzim razvojem novih tehnologija, a dječje se knjižnice trebaju prilagoditi novim navikama svojih korisnika. Stoga dječji knjižničari i knjižničari za mlade trebaju pratiti tehnološke promjene i načine učenja i provođenja slobodnog vremena svojih korisnika kako bi mogli kreirati odgovarajuće usluge i programe kao što su promoviranje djela mašte, poticanje čitanja, promoviranje popularno-znanstvene literature i podupiranje učenja, omogućavanje slobodnog pristupa raznim izvorima i medijima. Knjižničari pružaju i potporu za usvajanje vještina i znanja svih vrsta pismenosti, što su opće poznate zadaće knjižnica za djecu i mlade. Nakon rasprave istaknut je zaključak da je nužno uključivanje knjižnica u nove trendove, posebice u odnosu na nove tehnologije koje su djeci i mladima bliske te da knjižničari koji rade s djecom i mladima trebaju ići u korak sa svojim korisnicima pružanjem usluga i programa

35 Cjeloviti program Skupa nalazi se na mrežnoj stranici HKD-a: https://hkdrustvo.hr/hr/strucna_tijela/17/publikacija/284. 
i u virtualnom okruženju. Pri tome treba uzeti u obzir vrijednosti komunikacije uživo s djecom i mladim korisnicima i pozitivan doživljaj aktivnosti održane uživo, što svakako treba nastaviti prakticirati. Skupom se jačaju kompetencije dječjih knjižničara iz područja digitalne pismenosti te ponovno, poznavanja i korištenja novih tehnologija.

Sudjelovanje knjižnice u promicanju razvoja civilnog društva jedna je od njezinih temeljnih zadaća, što je ugrađeno u sve važnije strukovne dokumente. Knjižnice kao javne ustanove prepoznate su kao institucije otvorene svima i okrenute općem dobru. Tradicija aktivnog sudjelovanja naših dječjih knjižnica u stvaranju civilnog društva potječe još iz druge polovice prošlog stoljeća kada su u suradnji sa Savezom društava „Naša djeca“ počele provoditi aktivnosti vezane uz promicanje prava djeteta kao što su dječji forumi. Dječje knjižnice danas na razne načine osvještavaju djecu i mlade o važnosti građanske aktivnosti i hrabrosti. Stoga se stručni skup „Dječje knjižnice i civilno društvo“ (18. ožujka 2016.) tematski bavio suradnjom knjižnica s organizacijama civilnog društva, osvještavanjem i poticanjem na aktivno sudjelovanje djece i mladih u lokalnoj zajednici, promicanjem vrijednosti volontiranja isticanjem i mogućnostima na koje se načine knjižnice mogu uključiti u rješavanje problema koji su od javnog interesa, posebno u odnosu na djecu i mlade. U pozvanim izlaganjima istaknuta je važnost društveno angažiranog knjižničarstva te shvaćanja knjižnica kao prostora koji provode politiku otvorenosti i slobode izražavanja i podržavaju aktivnosti građanskih inicijativa, a održali su ih I. Kordić „Volontiranje kao pokretačka energija vitalnog i demokratskog društva“, M. Hibert „Pirati u bibliotekama“ i G. Ribičić „Treći prostor za treći sektor - zajednička uloga u demokratizaciji društva i aktivitetu građana“. Prikazanih deset primjera dobre prakse iz Pazina, Zagreba, Rijeke, Novigrada, Karlovca, Splita i Bjelovara svjedoče da hrvatske knjižnice surađuju s organizacijama civilnog društva te potiču djecu i mlade na aktivno uključivanje u život zajednice. ${ }^{36}$ Kao zaključak skupa istaknuto je da su knjižnice javne i otvorene ustanove i kao takve pogodna mjesta za građanski odgoj djece i mladih i provedbu raznih aktivnosti s ciljem promicanja vrijednosti civilnog društva i demokratskih načela, pri čemu je dobrodošla suradnja knjižnica s organizacijama civilnog društva. Skupom se jačaju kompetencije dječjih knjižničara s polja suradnje, ljudskih prava i poznavanja načina društvenog aktivizma.

Stručni skup „Informacijska pismenost u dječjim knjižnicama“ održan 31. ožujka 2017. godine bio je posvećen važnosti informacijske pismenosti u modernom informacijskom okruženju te teorijskim postavkama i praktičnim metodama informacijskog opismenjavanja djece i mladih u narodnim i školskim knjižnicama, organizaciji i provedbi programa informacijske pismenosti te uočenoj potrebi za dodatnom edukacijom knjižničara, učitelja i drugih pedagoških djelatnika koji

36 Cjeloviti program Skupa s video snimkom pozvanih izlaganja nalazi se na mrežnoj stranici HKD-a: https://hkdrustvo.hr/hr/strucna_tijela/17/publikacija/317. 
rade na tom području. Koncept informacijske pismenosti nije novina. Iako je u središtu zanimanja struke, jer je upravo poticanje razvoja vještina informacijske pismenosti među djecom i mladima središnja zadaća knjižničara, još uvijek nije u dovoljnoj mjeri u društvenom fokusu kao životno važna vještina, niti postoji sustavan način poučavanja vještinama informacijske pismenosti od dječje dobi u odgojno-obrazovnom sustavu. Stoga je skup bio dobra prilika za progovaranje o toj problematici. Uz tri pozvana izlaganja I. Ljubunčić „What is the answer to life, the universe and everything?“, S. Špiranec „Informacijska pismenost: od funkcionalnih prema kritičkim pristupima“ te S. Vidmar i P. Kavčič „Rastem s e-izvorima“ predstavljeno je i sedam primjera dobre prakse iz narodnih knjižnica iz Bjelovara, Čakovca, Koprivnice, Zadra i Zagreba te tri primjera iz školskih knjižnica iz Krapine, Marije Bistrice i Zlatar Bistrice. ${ }^{37}$ Sudionici skupa dobili su uvid u novije teorijske spoznaje i raznoliku praksu u hrvatskim narodnim i školskim knjižnicama na području informacijskog opismenjavanja. Nakon rasprave zaključeno je da je informacijska pismenost nužna u okruženju poplave informacija i brzih promjena u informacijsko-komunikacijskoj tehnologiji. Knjižničari kao informacijski stručnjaci trebaju imati aktivnu ulogu u informacijskom opismenjavanju, a knjižnice se trebaju nametnuti kao središnja informacijska mjesta i mjesta cjeloživotnog neformalnog učenja. Skupom se jačaju kompetencije dječjih knjižničara vezane za razvoj i provedbu usluga informacijskog opismenjavanja.

Nužna je suradnja knjižnica sa svima koji sudjeluju u nastanku knjiga i promicanju vrijednosti čitanja. Upravo su festivali knjiga dobra prilika za to jer na jednom mjestu okupljaju sve iz knjižarskog lanca, književnike, ilustratore, urednike, prevoditelje, nakladnike, knjižare, knjižničare, pripovjedače i čitatelje, a obuhvaćaju i cijele lokalne zajednice do nacionalne razine. Knjižnice festivale knjiga prepoznaju kao potencijal za ostvarenje svojih ciljeva. Stručni skup „Suradnja dječjih knjižnica i festivala knjiga“ (23. ožujka 2018.) ponajprije se bavio suradnjom dječjih knjižnica s festivalima i drugim sličnim manifestacijama koje promoviraju dječje knjige i čitanje za učenje, osobni razvoj i iz užitka. Pozvana izlaganja održali su A. Peti-Stantić „Čitanje u mozgu za čitanje u društvu“, A. Kožul „Suvremena književnost i čitanje kod mladih: primjer književnih matineja“ te J. Petrović i M. Matijević, „Festival dječje knjige u Srbiji“. U dijelu s pozvanim izlaganjima primjera dobre prakse izlaganja su održale S. Lovrenčić, D. Petrić i V. Štivić „Uberi priču!“, A. Đokić i M. Marušić „Festival slikovnice Ovca u kutiji“, B. Ivanković „Promocija narodnog stvaralaštva kroz Dane Balinta Vujkova“, N. Crkvenac „U knjižnicu na Nulti dan: od 2012. do 2017. godine“ te M. Bakmaz i Ž. Žentil Barić „Zadar čita“, a prikazano je još šest prijavljenih primjera dobre prakse iz Zagreba, Virovitice, Rijeke i Požege, kao i iz Srbije. Na kraju skupa predstavljena je knjiga knjižničara K. Mijatova i R. Benić, u izdanju Gradske knjižnice

37 Cjeloviti program Skupa s video snimkom pozvanih izlaganja nalazi se na mrežnoj stranici HKD-a: https://hkdrustvo.hr/hr/strucna_tijela/17/publikacija/373. 
Beli Manastir „Što ako knjigu iz knjižnice pojede pas?“.38 U prostoru knjižnice Medveščak bila je postavljena i prigodna izložba koja se mogla razgledati tijekom stanki. Zaključak je skupa da zajedničko usmjereno djelovanje na popularizaciji knjiga i čitanja doprinosi boljoj vidljivosti svih uključenih u lancu knjige. Aktivnostima tog tipa obuhvaća se veći broj populacije za provedbu ciljeva kao što je povezivanje knjige i mladih čitatelja. Festivali su svakako dobra prilika za učenje i razmjenu znanja i iskustva u stručnoj zajednici, a knjižničari kao stvaratelji popratnih aktivnosti su dodana vrijednost festivalima. Skup je još jednom ponudio sadržaje kojima se jačaju kompetencije dječjih knjižničara vezane za suradnju te promicanje kulture čitanja.

Skup pod nazivom „Sadržajna obrada i klasifikacija građe u dječjoj knjižnici“ održan je 29. ožujka 2019. godine, a organizirale su ga dvije HKD-ove komisije, Komisija za knjižnične usluge za djecu i mladež i Komisija za klasifikaciju i predmetno označivanje te Knjižnice grada Zagreba - Knjižnica Medveščak. Tema sadržajne obrade, klasifikacije i signiranja građe netipična je za skup prvenstveno namijenjen dječjim knjižničarima, no predložili su je sami knjižničari koji rade u dječjim knjižnicama koji se u svakodnevnom radu susreću s izazovom dostupnosti i pristupačnosti građe te uvažavanja korisničkih potreba i navika. Na skupu su se okupili dječji i školski knjižničari te knjižničari koji se bave stručnom obradom građe. Pozvana izlaganja održali su stručnjaci koji se bave sadržajnom obradom građe: D. Cupar „Sadržajni pristup građi namijenjenoj djeci i mladima: teorijski aspekti““, M. Kenda i N. Tomšič „Sustav oznaka riječima: razmještaj građe za djecu i mlade u Mestni knjižnici Kranj“, K. Kemperle „Knjiga te čeka, potraži ju!: novi razmještaj lijepe književnosti na odjelu za mlade MKL prema čitalačkim gledištima“ i S. Mikačić „Književnost za mladež i potreba za klasifikacijskim definiranjem i razlikovanjem njezinih dobnih značajki“. Knjižničari iz narodnih knjižnica iz Ljubljane, Zagreba, Splita, Siska i Bjelovara prikazali su sedam primjera iz prakse. ${ }^{39}$ Sadržajna obrada i klasifikacija knjižnične građe jedni su od temeljnih poslova u knjižnicama. S obzirom na to da je cilj klasifikacije i sadržajne obrade građe omogućiti korisnicima i knjižničarima jednostavno pronalaženje potrebnog i željenog sadržaja, to je značajniji posao koji knjižničari rade kako bi stručno obradili knjižničnu građu. Koliko je to zahtjevan i delikatan posao znaju svi knjižničari i, iako se klasifikacija i sadržajna obrada rade po pravilima koja većinu postupaka detaljno propisuju, nije jednostavno sve što pristiže u knjižnicu opisati, posebno raznoliku knjižničnu građu za djecu, pa su skupovi koji se bave tom temom itekako potrebni. Zaključci su doneseni nakon žive rasprave stručne zajednice sudionika stručnog skupa, gdje se istaknulo da je potrebno provesti

\footnotetext{
38 Cjeloviti program Skupa s video snimkom pozvanih izlaganja nalazi se na mrežnoj stranici HKD-a: https://hkdrustvo.hr/hr/strucna tijela/17/publikacija/443.

39 Cjeloviti program Skupa nalazi se na mrežnoj stranici HKD-a: https://hkdrustvo.hr/hr/strucna_tijela/17/publikacija/516.
} 
istraživanje stanja u Hrvatskoj te stvarnih korisničkih potreba kako bi se pitanjima sadržajne obrade, klasifikacije te signiranja građe za djecu i mladež pristupilo na stručno utemeljen način te je potrebno donijeti smjernice za sadržajnu obradu, klasifikaciju i signiranje građe koje bi se primjenjivale na nacionalnoj razini. Skupom se jačaju kompetencije dječjih knjižničara za sadržajnu obradu knjižnične građe.

Planirani stručni skup „Inovativna dječja knjižnica: primjena novih tehnologija“" koji se trebao održati krajem ožujka 2020. godine u prostoru Knjižnice Medveščak, zbog pandemije bolesti COVID-19 odgođen je te održan 22. rujna iste godine $\mathrm{u}$ izmijenjenom, virtualnom obliku putem Zoom platforme za videokonferencije. Kao takav, bio je prvi od mnogih HKD-ovih skupova koji su zbog epidemiološke situacije održani virtualno, što je samo po sebi inovativno. U uvodnom dijelu izlaganja su održali I. Martinović „Nove tehnologije u dječjim knjižnicama: hit, hir ili potreba?“, A. Sović Kržić „,Roboti na satu lektire“ i N. Bakić „Knjižnice - mjesta znanja i novog doba“, a trinaest primjera dobre prakse iz Zagreba, Rijeke, Osijeka, Zadra, Koprivnice, Gunje, Vinkovaca i Čakovca prikazali su niz primjera uspješne primjene nove tehnologije u dječjim knjižnicama u Hrvatskoj. ${ }^{40}$ Primjena novih tehnologija u dječjim knjižnicama doprinosi poboljšanju usluga, programa i projekata putem inovativnih i kreativnih načina osiguravanja pristupa informacijama, poticanja čitanja, pružanja potpore svim oblicima učenja te uspješnom zadovoljavanju potreba i ostvarivanju prava djece koja odrastaju u suvremenom digitalnom okruženju. Na skupu je zaključeno kako je knjižnica kao mjesto stvaralačkog znanja i neformalnog učenja mjesto primjereno digitalnim tehnologijama koje je potrebno integrirati u rad knjižnica kao sredstvo poticaja, inspiracije, obrazovanja i razvoja djece i mladih. Posebno je naglašeno da je sustav javnih knjižnica dio važne javne infrastrukture u Hrvatskoj, čiji su resursi dostupni svima te su knjižnice idealne za sve oblike neformalnog učenja. Upravo to je ono što knjižnicama daje veliku vrijednost i otvara brojne transformacijske mogućnosti kako za same knjižnice tako i za djecu i mlade koji se knjižnicom koriste. Skup je još jednom, u skladu s trendovima i brzim razvojem tehnologije, sudionicima ponudio sadržaje koji pogoduju jačanju kompetencija poznavanja i primjene specifičnih novih tehnologija.

Stručni skup na temu razvojne biblioterapije u dječjoj knjižnici održan je 26. ožujka 2021. godine na Zoom platformi pod nazivom „Biblioterapijski pristup u radu s djecom i mladima u knjižnici“. Knjižnica je prirodno okruženje za primjenu razvojne biblioterapije, ima kvalitetan knjižni fond s odabranim čitateljskim materijalima i knjižničare koji posjeduju kompetencije za provedbu aktivnosti koje uključuju elemente razvojne biblioterapije i vođenog čitanja. No mnogi dječji knjižničari nesigurni su i pitaju se mogu li provoditi takve aktivnosti jer radi se o iznimno osjetljivom području koje graniči s rehabilitacijom i liječenjem, za što

40 Cjeloviti program Skupa nalazi se na mrežnoj stranici HKD-a: https://hkdrustvo.hr/hr/strucna_tijela/17/publikacija/592. 
knjižničari nemaju kompetencije niti to smiju samostalno raditi. Taj je skup organiziran s namjerom kako bi se odgovorilo na navedeno pitanje i pokazali primjeri dobre prakse iz hrvatskih knjižnica. Tema je privukla iznimno velik broj sudionika, što je pokazatelj njezine važnosti za knjižničnu zajednicu. Pozvana izlaganja održali su: D. Piskač „Literarna biblioterapija u kontekstu pametnog čitanja“, I. Bašić „Osnovni principi i ciljevi razvojne biblioterapije“ i Lj. Sabljak „Rekreativno, biblioterapijsko čitanje u knjižnici“. Knjižničari iz Zagreba, Čakovca, Krapine i Osijeka prikazali su pet primjera dobre prakse, a predstavnice HKD-ove Komisije za knjižnične usluge za djecu i mladež predstavile su popis književno-umjetničkih tekstova po temama koji mogu poslužiti učiteljima i drugim pedagoškim djelatnicima kao poticaj za razgovor (na primjer o poremećaju u prehrani) i drugu primjenu u odgojno-obrazovnom radu. ${ }^{41}$ Zaključci skupa upućuju na to da knjižničari mogu primjenjivati biblioterapijski pristup u provođenju programa za djecu radi uspješnijeg ostvarenja zadaća dječje knjižnice i njezinog pozitivnog utjecaja na cjelokupni rast i razvoj odrastajuće populacije knjižničnih korisnika u zdrave pojedince koji onda čine i zdravo društvo. Dječje knjižnice stvaraju pozitivna okružja koja djecu čine slobodnom i opuštenom te takve aktivnosti doživljavaju pozitivno, što su preduvjeti za uspješnu provedbu razvojne biblioterapije. Uloga knjižničara vezana uz biblioterapijski pristup može imati nekoliko stupnjeva, od preporuke za čitanje i nestrukturiranog razgovora o knjigama do poučavanja korisnika za čitanje s razumijevanjem i vođeno čitanje. Najviši je stupanj pomaganje da korisnik doživi zdrave emocije i uspješno ih kanalizira (od čitanja preko doživljaja i emocije do spoznaje i reakcije), za što je potrebna dodatna edukacija knjižničara. Koji će oblik biblioterapijskog pristupa knjižničar odabrati ovisi o korisničkoj populaciji, njihovim sposobnostima i uočenim potrebama, pristupu problematici, kompetencijama knjižničara i zadanim ciljevima, pri čemu svakako treba imati u vidu knjižnični kontekst. Skupom se jačaju kompetencije dječjih knjižničara vezanih za prepoznavanje korisničkih potreba te osmišljavanje, planiranje i vođenje specifičnih programa.

Za 2022. godinu planira se stručni skup pod nazivom „Od klasifikacije do brisanja nosa: kompetencije dječjeg knjižničara" koji će se baviti samim kompetencijama dječjih knjižničara, a održat će se hibridno (u Knjižnici Medveščak i na Zoom platformi) ako za to budu pogodni epidemiološki uvjeti. Naime, u doba pandemije kada su se stručni skupovi održavali putem alata za mrežne videokonferencije uvidjelo se da je skupovima pristupilo mnoštvo knjižničara iz školskih i narodnih knjižnica iz udaljenih dijelova Hrvatske jer nije bilo financijskih i vremenskih prepreka za pristup i sudjelovanje u njihovom neophodnom stručnom usavršavanju.

${ }^{41}$ Cjeloviti program Skupa nalazi se na mrežnoj stranici HKD-a: https://hkdrustvo.hr/hr/strucna_tijela/17/publikacija/593. 


\section{Zaključak}

Knjižničari koji rade na dječjim odjelima ili odjelima za djecu i mlade, rade s posebnom skupinom korisnika koja je posebna po mnogim značajkama u odnosu na druge korisnike knjižnice i koju odlikuju česte promjene i raznolikost. Danas u knjižnice roditelji učlanjuju djecu gotovo od rođenja, dok su među najvjernijim korisnicima djeca predškolskog i osnovnoškolskog uzrasta, a tu su još i mlađi tinejdžeri. Među svima njima velika je razlika u sposobnostima, znanjima, potrebama i željama. Korisnici dječjih knjižnica su i svi odrasli koji sudjeluju u odgoju i obrazovanju ili se na neki drugi način, privatno ili profesionalno, bave djecom. Za sve njih treba izgraditi primjeren i kvalitetan fond i pružiti im odgovarajuće usluge i programe.

$\mathrm{Na}$ rad dječjeg knjižničara utječu i promjene u društvu koje djeluju na više razina knjižničnog poslovanja, uključujući, na primjer, radno vrijeme, organizaciju rada, komunikaciju s korisnicima, status pismenosti i kulture u društvu, ozračje dječje knjižnice i drugo. Treba još istaknuti ubrzani razvoj novih tehnologija koje najprije prihvaćaju mlade generacije, pa knjižničari koji rade s njima nužno trebaju savladavati nove programe, alate, društvene mreže i sve vezano uz nove informacijsko-komunikacijske kanale.

Stalno stručno usavršavanje i stjecanje potrebnih kompetencija dječjih knjižničara nastoji se osigurati od 2006. godine do danas na stručnim skupovima u organizaciji Hrvatskog knjižničarskog društva - Komisija za knjižnične usluge za djecu i mladež i Knjižnice grada Zagreba - Knjižnice Medveščak. Skupovi za knjižničare za djecu i mladež kroz nepromijenjen velik interes stručne zajednice te visoke ocjene prikupljene u evaluacijskim upitnicima na završetku svakog skupa, pokazuju da su takva stručna događanja za knjižničare iz cijele Hrvatske koji rade $\mathrm{s}$ djecom ne samo potrebna nego i neophodna. Naime to je jedini redoviti skup te razine koji u isto vrijeme svake godine i na istom mjestu od 2006. godine okuplja dječje knjižničare iz Zagreba, Hrvatske i inozemstva, te im pruža mogućnost upoznavanja teorijskih novina u dječjem knjižničarstvu i razmjenu iskustava dobre prakse.

\section{LITERATURA}

Competencies for information professionals of the $21^{\text {st }}$ century. Revised ed. June 2003. [citirano: 2021-05-05]. Dostupno na: https://sla.org/wp-content/uploads/2013/01/0_ LRNCompetencies2003_revised.pdf.

Competencies for librarians serving children in libraries. Chicago: American Library Association, 2015. [citirano: 2021-10-01]. Dostupno na: https://www.ala.org/alsc/ 
sites/ala.org.alsc/files/content/151105_alsc_core-competencies-booklet-nobleeds. pdf.

Guidelines for children's library services. The Hague: IFLA Libraries for Children and Young Adults Section, 2003.

Guidelines for children's services. / ed. by A. M. Fasick. The Hague: IFLA Headquarters, 1991.

Guidelines for library services for young adults. / priredili P. Muller and I. Chew The Hague: IFLA Headquarters, 1996.

IFLA-ine smjernice za knjižnične usluge za djecu od rođenja do 18 godina. / Sastavila IFLA-ina Sekcija za knjižnične usluge za djecu i mladež; uredila C. Rankin; prijevod G. Tuškan. 2. izd. (revizija Smjernica iz 2003. godine). Den Haag: IFLA Library Services to Children and Young Adults Section, 2018. [citirano: 2021-10-05]. Dostupno na: https://www.hkdrustvo.hr/hr/strucna_tijela/17/publikacija/599.

IFLA/UNESCO Public library manifesto 1994. [citirano: 2021-05-06]. Dostupno na: https://repository.ifla.org/handle/123456789/186.

Klaić, Bratoljub. Rječnik stranih riječi: Tuđice i posuđenice. Zagreb: Nakladni zavod Matice hrvatske, 1990.

Konvencija o pravima djeteta. [citirano: 2021-06-08]. https://www.unicef.hr/wp-content/uploads/2017/05/Konvencija_20o_20pravima_20djeteta_full.pdf.

Koren, M. Pravo djece na informaciju: Vezanost ljudskih prava s knjižničnim uslugama. // Slobodan pristup informacijama u službi kulturnog razvitka: Zbornik radova. / uredile A. Belan-Simić i A. Horvat. Zagreb: Hrvatsko knjižničarsko društvo, 2002.

Martinović, I; I. Stričević. Kompetencije dječjih knjižničara: Koliko poznaju literaturu za svoje korisnike. // Vjesnik bibliotekara Hrvatske 56, 3(2013). [citirano: 2021-0510]. Dostupno i na: https://www.hkdrustvo.hr/vjesnik-bibliotekara-hrvatske/index. $\mathrm{php} / \mathrm{vbh} /$ article/view/163/158.

McColvin, L. R. Public library services for children. Paris: UNESCO, 1957. [citirano 2021-05-31]. Dostupno i na: https://unesdoc.unesco.org/ark:/48223/pf0000053875/ PDF/053875engb.pdf.multi.

Milinović, M. Školske knjižnice - prirodni partneri dječjih knjižnica. 2010. [prezentacija][citirano 2021-06-07]. Dostupno na: https://www.hkdrustvo.hr/hr/skupovi/ skup/165/sazetak/52.

Smjernice za informacijsku pismenost u cjeloživotnom učenju: Završna verzija. / uredio J. Lau. Zagreb: Hrvatsko knjižničarsko društvo, 2011.

Smjernice za knjižnične usluge za bebe i djecu rane dobi. / glavna urednica M. Willer. Zagreb: Hrvatsko knjižničarsko društvo, 2008.

Smjernice za knjižnične usluge za djecu: Knjižnične usluge za djecu - važnije no ikada za djecu i njihove obitelji diljem svijeta / IFLA, Sekcija za djecu i mladež; s engleskoga prevela I. Kranjec. Zagreb: Hrvatsko knjižničarsko društvo, 2004. 
Smjernice za knjižnične usluge za mladež. / s engleskog prevela I. Kranjec; urednica M. Willer. Zagreb: Hrvatsko knjižničarsko društvo, 2004. (Povremenena izdanja HKD-a; knj. 7)

Smjernice za knjižnične usluge za mladež. Prerađeno izdanje Smjernica koje je 1996. objavio Stalni odbor Sekcije knjižnica za djecu i mladež. / glavna urednica A. Barbarić. Zagreb: Hrvatsko knjižničarsko društvo, 2009.

Stričević, I. Dječja knjižnica ukorak s vremenom. // Dječja knjižnica za novo tisućljeće: Zbornik. / uredila R. Javor. Zagreb: Knjižnice grada Zagreba, 2001.

Stričević, I. IFLA-ine Smjernice za knjižnične usluge za bebe i djecu do tri godine: Radna verzija. (19. 3. 2007.) [prezentacija][citirano: 2021-05-06]. Dostupno na: https:// www.hkdrustvo.hr/hr/skupovi/skup/96/sazetak/83.

Visinko, K. Kultura čitanja u procesu odrastanja. (14.03.2008.) [prezentacija][citirano: 2021-05-06]. Dostupno na: https://www.hkdrustvo.hr/hr/skupovi/skup/122/saze$\operatorname{tak} / 27$.

Walter V. A.; E. Meyers. Teens and libraries: Getting it right. Chicago: American Library Association, 2003. 